\title{
ID2 Gene
}

National Cancer Institute

\section{Source}

National Cancer Institute. ID2 Gene. NCI Thesaurus. Code C28587.

This gene plays a role in the regulation of both transcription and cell proliferation. 